\title{
A 10-year Analytical Review of New Russian Medical Journals (2010-2019)
}

\author{
E. G. Raevskaya ${ }^{a, *}$ and T. V. Stogova ${ }^{a, * *}$ \\ ${ }^{a}$ All-Russian Institute for Scientific and Technical Information, Russian Academy of Sciences, Moscow, Russia \\ *e-mail:raevs@viniti.ru \\ **e-mail: stogova@viniti.ru
}

Received June 15, 2021

\begin{abstract}
This article presents the results of the analysis of peer-reviewed periodical scientific medical journals founded in Russia over the past 10 years (2010-2019). The selection process was carried out using a specially developed methodology, which made it possible to identify 84 Russian medical journals with an emphasis on practical medicine, which were included in international databases (DBs): Ulrich's Periodicals Directory and two leading information and analytical systems: Scopus, and Web of Science. With the use of information and analytical tools provided by these databases, as well as two Russian resources, eLIBRARY.RU and the database of VINITI RAS, the subject classification of journals, publishing houses, the language of publications, access to publications, along with their available bibliometric indicators have been determined. A good result was observed regarding the integration of the analyzed editions into the Scopus (22 out of 84) and Web of Science (5 out of 84) international databases. A discrepancy in the subject classification of journals has been revealed between various databases. All the considered classifiers had different results, with the most detailed subject specification found for the system of in-depth indexing of topics using both the State Classifier of Scientific and Technical Information and the Rubricator of VINITI RAS, which provides the most accurate structuring of information that facilitates rapid and effective searching for data.
\end{abstract}

Keywords: medicine, Russian medical scientific journals, databases, Ulrich's Periodicals Directory, Scopus, Web of Science, All-Russian Institute for Scientific and Technical Information of Russian Academy of Sciences database, eLIBRARY.RU, indexing, subject classification system, subject category

DOI: $10.3103 / \mathrm{S} 0147688221030114$

\section{INTRODUCTION}

Medicine is of great importance for maintaining the good quality and longevity of life for every person; therefore the relevance of this topic always remains very high. Moreover, in recent years, the role of medicine has grown even more due to the unexpected emergence of previously unknown challenges and threats, one example of this is the COVID-19 coronavirus pandemic, which has been going on for the past 2 years.

In this regard, it is very important that the achievements of medical science would be introduced into practice as soon as possible and scientific medical publications can help in this by providing timely information. The total number of currently published medical journals is quite large; their ratio related to the total number of scientific periodic editions is also high. According to the Ulrich's Periodicals Directory international bibliographic periodical directory [1] (the most complete source of information about more than 138000 scientific periodicals), scientific journals on medical topics occupy $28 \%$ of it (35925), i.e., almost a third of the total volume of scientific periodicals in this database (DB). Similarly, in Scopus, the leading international DB (Elsevier, the Netherlands), the share of medical journals also accounts for $\sim 28 \%$ of all journals indexed in it (7322 out of a total of 26201) [2, 3]. In one of the largest databases of scientific publications, the Web of Science (Clarivate Analytics, United States), about $40 \%$ of the journals included in the Journal Citation Reports (JCR) list are related to medical subjects [4, 5].

In the Russian Federation, the improvement of medicine has been declared as one of the priority directions for the development of science, engineering, and technology ${ }^{1}$. Medicine and healthcare are among the key areas in forecasting the scientific and technological development of Russia until $2030^{2}$. In 2019, a broad-scale high-priority national project

\footnotetext{
${ }^{1}$ The Strategy for Scientific and Technical Development of the Russian Federation. The Decree of the President of the Russian Federation as of December 1, 2016, No. 642. URL: http://base.garant.ru/71551998/

2 The Forecast of Scientific and Technological Development of the Russian Federation for the Period until 2030. URL: http://static.government.ru/media/files/41d4b737638b91da2184.pdf
} 
code-named 'Healthcare' has been launched in Russia which will run until $2024^{3}$.

At first glance, the total number of medical periodicals published in Russia seems to be rather high, but further analysis shows that their ratio is modest, not only in comparison with the corresponding world data, but also among domestic scientific journals in all the areas of science. According to the eLIBRARY.RU scientific electronic library [6], at the time of writing this article, it contained information on 1228 currently published Russian scientific journals on the topic of Medicine and Healthcare with the total number of active journals in Russia, 12038, which is only $\sim 10 \%$. The ratio of Russian medical serials in the total world scientific literature flow is even smaller; for example, in 2019, the Scopus DB included only 136 Russian journals with the Medicine subject category, which was less than $2 \%$ of the total number of medical journals in this database [2].

Recent studies devoted to the analysis of Russian medical journals $[5,7-11]$ and related subjects $[12,13]$ show their insufficient representation in international databases. The authors of these publications associate this fact, first of all, with shortfalls of the requirements for high-quality scientific periodicals [5, 8, 14]. Nevertheless, the results of the evaluation of 1000 Russian medical journals, which was carried out by the authors of $[5,7,8]$, show that about 300 of them are of a sufficiently high quality and could be candidates for inclusion in the Scopus DB. In addition, the problems of a wide scattering of medical publications in different journals and the complexity of filling empty subject niches were demonstrated.

In this regard, the goal of this article is to analyze new periodicals on medicine that have appeared in Russia over the past 10 years (2010-2019); moreover, with limitation to the journals which are presented in the main international databases of scientific periodicals and thus are available to the international scientific community. For this purpose, a study of their subject categories, publication format, distribution by type of publisher, representativity in various databases, accessibility and other characteristics was carried out, and a preliminary assessment of their quality was given using the currently accepted scientometric indicators of their rating.

\section{MATERIALS AND METHODS}

Our research is a part of the study carried out at the Technological Department of the large information center: the All-Russian Institute for Scientific and Technical Information (VINITI RAS), where the world flow of scientific and technical literature has been constantly explored for many years, including

\footnotetext{
${ }^{3}$ Healthcare national project. URL: https://minzdrav.gov.ru/poleznye-resursy/ natsproektzdravoohranenie.
}

with the aim of identifying promising sources of scientific and technical information on natural, exact, and technical sciences.

The first step of our study started with a selection of Russian scientific medical journals that were established over the past 10 years, i.e., with their year of foundation in the period of 2010-2019; this selection was carried out according to the methodology developed at the Technological Department of the VINITI RAS using the international bibliographic directory of serial publications: Ulrich's Periodicals Directory (hereinafter, $U P D$ ) [1]. The data provided here was obtained at the time of writing this article (February 2021).

Figure 1 shows a scheme for selecting journals for analysis.

First, a query was made to the UPD DB using the following filters:

$$
\begin{aligned}
& \text { - Subject Area: Medicine and Health; } \\
& \text { - Status: Active; } \\
& \text { - Serial Type: Journal; } \\
& \text { - Content Type: Academic/Scholarly; } \\
& \text { - Key Feature: Refereed/Peer-reviewed; } \\
& \text { - Start year search: [2010 TO 2019]. }
\end{aligned}
$$

In response to the inquiry, a total of 3543 periodicals were extracted, of which 155 journals published in Russia were retrieved (which accounted for $4.4 \%$ of the total world flow of medical journals). Further, an in-depth analysis of their subject areas was carried out and those journals whose main content was not directly related to medicine, as well as medical-adjacent periodicals were deleted. The deleted topics were as follows: Biology, Business and Economics, Education, Health Facilities and Administration, Physical Fitness and Hygiene, Psychology, Pharmacy and Pharmacology, Nutrition and Dietetics, which yielded 100 titles remained in the list.

The foundation year of the periodicals was then checked using the information obtained on their websites and on the eLIBRARY.RU site, and 12 journals with the foundation year earlier than 2010 were found, which were removed from the list. The publication activities of the remaining editions were then checked and nine new journals were excluded, which, despite their recent introduction, unfortunately had been already ceased. Thus, the final number of new Russian scientific medical journals selected for analysis was established as 79 titles.

Finally, the eLIBRARY.RU website was used to identify five more journals related to the section (Medicine and Health) of the SRSTI rubricator with the year of foundation in 2010-2019, which were absent in the UPD DB, but were included in the $S c o-$ pus and Web of Science DBs. After adding these to the previously selected list, the final number of journals for analysis was fixed as 84 titles (Fig. 1). 


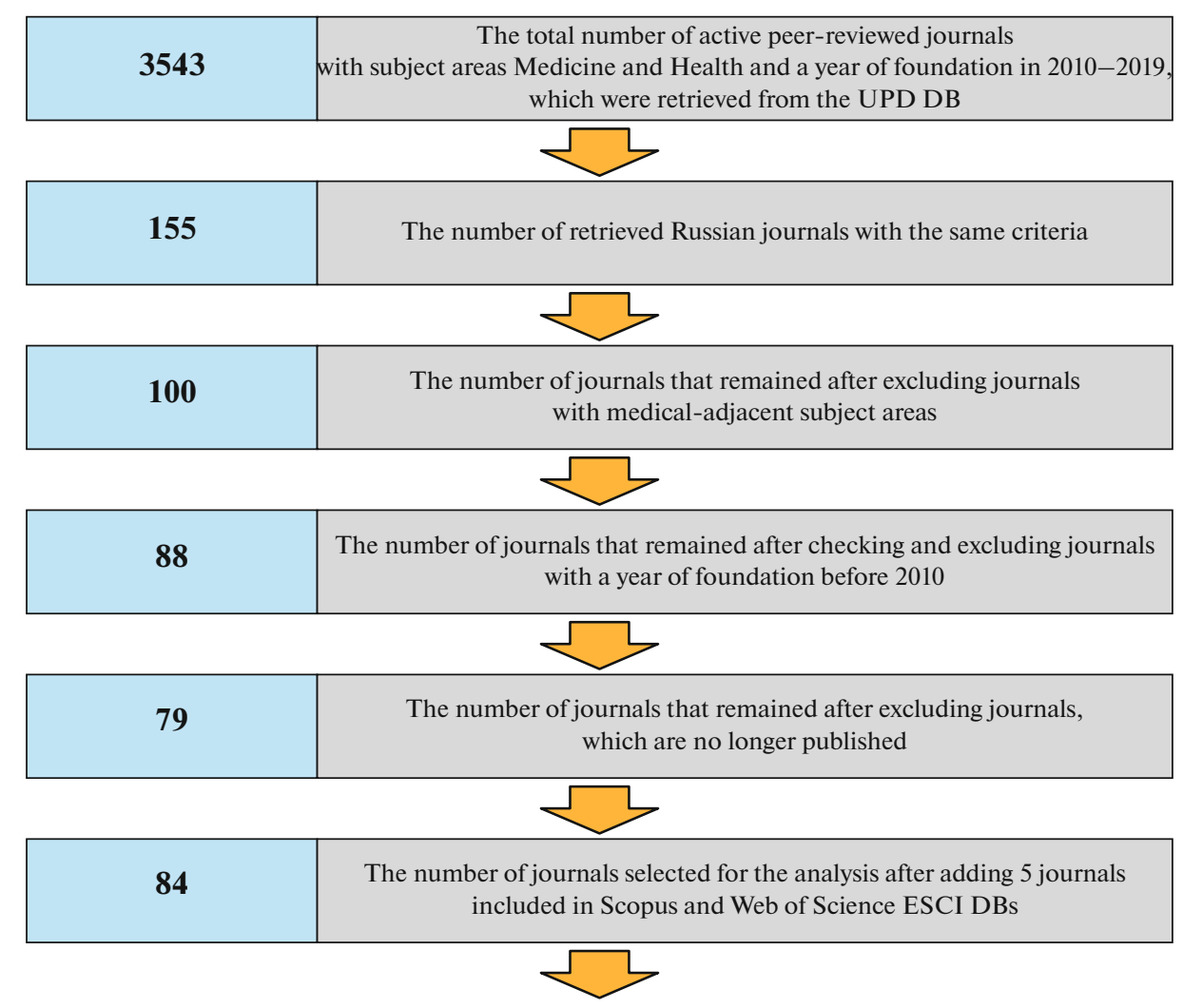

Fig. 1. The scheme for selecting for the analysis new Russian scientific medical journals with a year of foundation in 2010-2019, which are included in the Ulrich's Periodicals Directory, Scopus, and Web of Science Databases.

Data on the Scopus DB were obtained from the corresponding website of the Elsevier Publishing House [3], as well as from the analytical resource SCImago Journal and Country Rank developed by the University of Granada, Spain [2]; data on the Web of Science were obtained from the Web of Science Core Collection [15] and the annual report on scientific academic publications of this database: Journal Citation Reports (JCR) [4]. In addition, the search for information on the selected journals was carried out in Russian sources: eLIBRARY.RU [9], on the website of the Central Scientific Medical Library [16], as well as in the VINITI RAS Database: the Federal polythematic database of domestic and foreign publications on natural, exact, technical and applied sciences with a total volume of more than $33 \mathrm{mln}$ documents (coverage since 1981), which is updated monthly [17].

\section{RESULTS AND DISCUSSION}

It should be emphasized once again that in this study we are not considering all new Russian medical journals that have appeared over the past 10 years, but only those included in three large international databases: Ulrich's Periodicals Directory, Scopus, and Web of Science by the time of writing this article.
When starting this research, we planned to limit ourselves to considering the periodicals included in the $U P D$ reference $\mathrm{DB}$, but it turned out in the process of study that a small number of the journals had already entered the Scopus and Web of Science DBs, while bypassing the UPD. This is probably due to the fact that there are currently no uniform rules on how new journals must go ahead. Inserting a periodical in the $U P D$ DB seems to be expedient as a first step towards increasing the level of popularity of the new journal, which does not require much efforts to achieve high quality of articles and time for a sufficient number of citations to appear.

Thus, the rationale for limiting the number of analyzed journals is their reaching an international level when taking a step towards entering the aforementioned databases while general information about them (in the case of $U P D$ ) or even their contents (in the case of Scopus and Web of Science) become available to the global scientific community.

The second limitation applied in this work was the selection of journals directly related to practical medicine, which will be discussed in more details in the section on the subject areas of the selected serials. 
Table 1. The main characteristics of the analyzed array of scientific periodicals of the Russian Federation on medicine with the year of foundation in 2010-2019

\begin{tabular}{l|c}
\hline \multicolumn{1}{c|}{ Parameters } & Number of periodicals \\
\hline Total number of periodicals (active in 2019) & 84 \\
Have a website & $82^{*}$ \\
Have printed versions and provide full-texts on their websites & 61 \\
Have electronic versions only & 21 \\
Indexed in Scopus/Web of Science & $22 / 5^{* *}$ \\
Included in the eLIBRARY.RU/RISC Database / have the RISC impact factor & $83 / 70 / 57$ \\
Included in the RSCI Database & 11 \\
Included in the VINITI RAS Database/ obligatory indexing & $56 / 32^{* * *}$ \\
Available in the State Central Scientific Medical Library DB & 58 \\
Included in the list of Higher Attestation Commission & 54 \\
Language of texts of articles: Russ. / Eng. / both & $67 / 8^{* * * * / 5}$ \\
Have free access to full texts of articles / after registration & $70 / 3$ \\
Have paid access to texts / partially paid (current year issues) & $2 / 7$ \\
\hline
\end{tabular}

* Two journals do not have a website, but their archive can be found at eLIBRARY.RU.

** Included in the Emerging Sources Citation Index (ESCI).

*** For three journals representing the English versions, the Russian-language version is indexed in VINITI.

**** Four journals are translated English versions.

\section{GENERAL CHARACTERISTICS OF THE ANALYZED ARRAY OF RUSSIAN MEDICAL JOURNALS WITH THE YEAR OF FOUNDATION IN 2010-2019}

As a result of the selection, only 84 items were included in the final table. Table 1 shows their main characteristics.

First of all, dominant trend towards the provision of information in electronic form is observed: almost all the journals (82) have their own websites with full texts of their articles, while one-fourth of these journals are published exclusively in online format (21). We also note a very good result in entering the world citation databases: one-quarter of the journals from the analyzed sample (22 titles) have already entered the Scopus DB (several of them are included in 2021 or have just received the approval of the application). Five journals have been included in the Web of Science DB, namely, in the Emerging Sources Citation Index (ESCI), which is a part of the Web of Science Core Collection with the option of their transition after a certain period of time to the Journal Citation Reports. Eleven other journals have been included in the Russian Science Citation Index (RSCI) DB hosted on the Web of Science platform, a joint product of the Scientific Electronic Library and Clarivate Analytics, which claims to match the collection of the best Russian scientific journals of the world level and currently numbers 803 titles [18].

We also checked the availability of publications from our list in the Medline bibliographic DB (a part of the PubMed DB) of the U.S. National Library of
Medicine, which is popular among physicians, and found there records of only one journal from our list: Advances in Gerontology.

The language of the texts of articles of periodicals is predominantly Russian $(80 \%)$, five use Russian and English, eight publish articles only in English, and four of them are translated versions of the main Russian version. All articles have abstracts in English and some journals even have abstracts in Chinese. As we noted above, there is no single model for the development of a journal, so some periodicals create separate translated English versions for promotion to the international level, while others either immediately publish all their content in English (possibly losing part of the Russian-speaking audience), or make the journal bilingual. The analyzed list includes two journals simultaneously with their translated English version: Bulleten' meditsinskoi nauki = Bulletin of Medical Science and Istoriya meditsiny = History of Medicine. Two more journals in our list are the emerging translated versions of the Russian original versions that have existed for a long time; these are Advances in Gerontology, which is the translated version of the journal Uspekhi gerontologii and Bulletin of Russian State Medical University, which is the translated version of the Vestnik RGMU journal, a scientific journal of the N.I. Pirogov Russian National Research Medical University; both of these translated versions are included in the Scopus and WoS ESCI DBs. However, these databases also include completely Russian-language journals (14) as well as bilingual ones (5), which may indicate that the quality of articles is no less important than their language. 
Naturally, the analyzed periodicals are well represented in Russian sources of information. The vast majority of the journals (70) are included in the database of the Russian Index of Science Citation (RISC) and have a 2-year RISC impact factor in the range from 0.079 to 1.418 . A fairly large number of the analyzed journals $(54.64 \%)$ is included in the list of peerreviewed scientific periodicals of the Higher Attestation Commission, providing authors with the opportunity to publish materials of their dissertation research.

It should be noted that most of the analyzed journals $(58$ or $\sim 70 \%)$ are available in the Central Scientific Medical Library of the I.M. Sechenov First Moscow State Medical University of the Ministry of Health of the Russian Federation, which is one of the largest medical libraries in Europe with a collection of more than $4 \mathrm{mln}$ items. Access to publications, including those from new Russian medical journals, is provided on the library website through electronic subscription [16].

The VINITI RAS DB contains 56 journals from the analyzed list; 33 of them are mandatory for indexing. A specific feature of the Institute's DB is in-depth thematic indexing, which will be discussed in more detail in the section on the subject areas of the journals.

It is important to note the open character of the new journals: most of them provide open access not only to bibliographic data, but also to the full texts of their articles (70, and 3 more after registration), and very few of them offer paid (2) or partially paid (7) access.

Figure 2 shows the dynamics of the foundation of new scientific medical journals in Russia over the past 10 years (2010-2019), if we consider only those journals that are currently included in the $U P D \mathrm{DB}$. For comparison, this figure shows data for the same period for medical scientific journals of all countries and also the total number of scientific journals in seven main areas of science and technology: Biological Sciences and Agriculture, Chemistry, Earth, Space, and Environmental Sciences, Mathematics, Medicine and Health, Technology and Engineering, and Physics. Taking into account the fact that the number of Russian medical journals is only a small part of the global flow, all three curves are visualized in the same figure but at different scales with an additional X-axis for the Russian journals on the right.

As can be seen from Fig. 2, the dynamics of the foundation of the new journals in 2010-2019 generally shows a decrease in their number by the end of the decade in all three cases. However, an increase was observed in 2013 for medical journals and those in the main fields of science and technology (two upper curves), while the descending for the Russian medical journals was more monotonous.

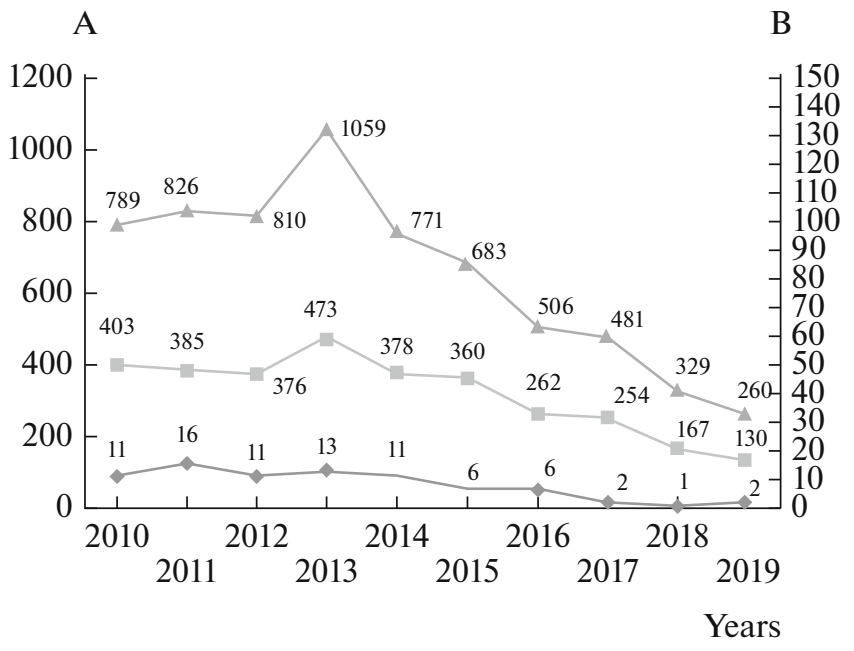

Fig. 2. The dynamics of the foundation of scientific and technical periodicals in 2010-2019 according to the UPD DB (from top to bottom): the total number of journals in the world for seven main areas of science and technology; the total number of medical journals in the world; the number of Russian medical journals; $\mathrm{A}$ is the ordinate axis with the number of journals for the two upper curves, B is the ordinate axis for the lower curve.

One of the reasons for the general decrease in the growth of the number of new journals in recent years is the policy of scientific administrators who demand that researchers from all over the world, including in Russia, must improve their publication activity indicators in order to increase personal and corporate ratings related to the influence and citedness of publication sources. The citation rate of well-known periodicals on authoritative platforms is expected to be higher than that for newly emerging journals, especially for those of little-known publishers, which creates serious difficulties for the development of domestic scientific journals.

New Russian medical journals are issued by 59 publishers. The distribution of journals by type of publisher is shown in Fig. 3, where it can be seen that almost half of all journals $(39,46 \%)$ are issued by publishing houses. Among them, we can note the three most active ones: the GEOTAR-Media publishing group (Moscow), which specializes in the publication of a wide range of medical literature (six journals from our list); the ABV-Press publishing house (Moscow), which is a specialized publisher that publishes periodical scientific, reference and methodological medical literature (six journals from our list), and one of the largest Russian medical publishing houses, Media Sphere (Moscow) (four journals). The second place is occupied by Russian universities; moreover, only four of them are located in Moscow (three journals) and St. Petersburg (one journal), while the rest are from Nizhny Novgorod, Smolensk, Ryazan, Samara, Arkhangelsk, Yakutsk, Ufa, Barnaul, Cheboksary, 


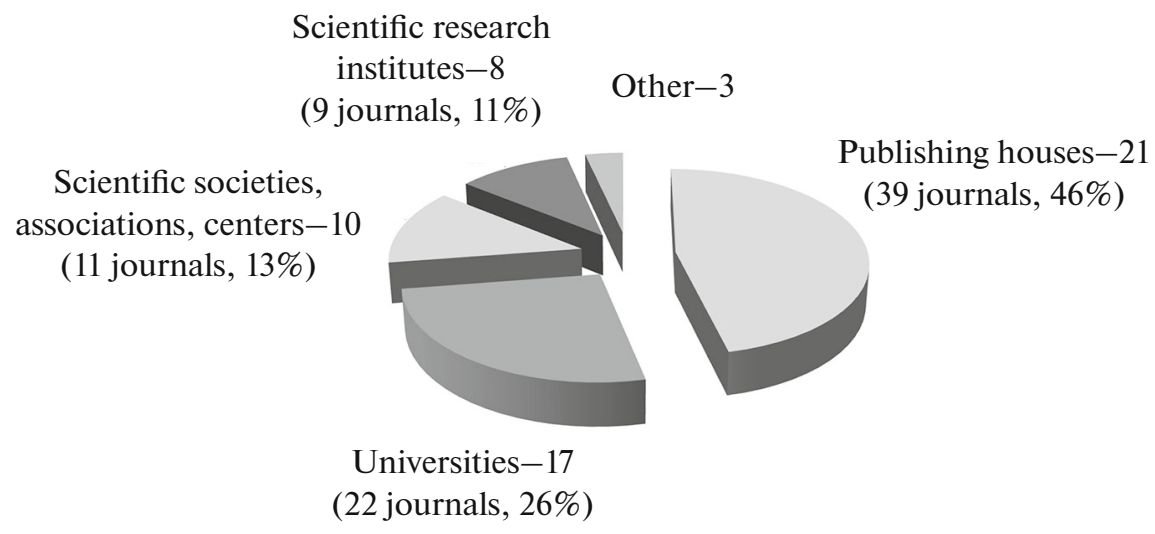

Fig. 3. Distribution by type of publisher for the new Russian medical journals with a year of foundation in 2010-2019, which are included in international DBs.

Rostov-on-Don, Krasnodar, Belgorod, Makhachkala. In general, the activity of the regions in the publication of new medical scientific periodicals is very high: almost two-thirds of the analyzed journals $(\sim 57 \%)$ are published in various cities of Russia and the rest of them are published in Moscow and St. Petersburg.

\section{SUBJECT AREAS OF NEW RUSSIAN MEDICAL JOURNALS}

We analyzed the subject areas of new Russian medical journals using a combination of several databases: $U P D$, eLIBRARY.RU, and VINITI RAS, since one database does not provide a complete picture of the coverage of all branches of science due to inconsistency in subject classification in different databases. The subject classifications of the Scopus and WoS DBs have their own peculiarities, which will be discussed in the corresponding section when analyzing the journals included in these databases.

At the first stage, the subject areas of the periodicals were analyzed in accordance with the UPD data. In the array of journals found in this database (79 titles), only 41 subject categories were identified that are used in the UPD for thematic rubrication. Among these categories, 19 belong to various sections of medical sciences (Medical Sciences) (a total of 32 headings are provided in the UPD DB in this category), and 12 belong to categories of other sciences (for example, Biology, Pharmacy and Pharmacology, Gerontology and Geriatrics, and Psychology). The distribution of journals by medical subject categories of the UPD DB is presented in Table 2, which shows that a significant part of the journals (44\%) is attributed to the general category Medical Sciences, while the rest of the more specific headings are rare, of which ten categories occur once or twice. Perhaps it is inappropriate to analyze the subject areas of publications using the UPD DB, since it has been created mostly for reference purposes.
To clarify the subject categories of our array, we used the data of the eLIBRARY.RU website, where the corresponding subject headings of the State Rubricator of Scientific and Technical Information (SRSTI) are given for each journal [19]. The results are shown in Fig. 4, which presents these categories for almost the entire array of analyzed journals (83).

In eLIBRARY.RU, twice as many subject categories were found: 86 SRSTI headings (compared to 41 UPD categories), although 55 of them are found only once; 52 of these headings $(\geq 60 \%)$ are directly related to medicine (section 76: Medicine and healthcare, as well as its subsections), while the frequency of their occurrence is quite high; they occur 177 times out of 230 (the total number of occurrences of all headings for all journals). Here, $58(\sim 70 \%)$ journals have a general category Medicine and Healthcare (76.00.00); the frequency of its occurrence is $25 \%$, and the rest of the journals are distributed over a very wide range of categories, which indicates the scattering of publications on various topics, which are mainly related to medicine.

More accurate and detailed information on the subject categories of articles in the relevant fields of research published in scientific and technical journals can be found in the VINITI RAS DB [17], which carries out thematic indexing of documents in accordance with the VINITI Rubricator of Knowledge Branches of the VINITI RAS developed at the VINITI [20]: a classification scheme for universal coverage in natural and technical scientific disciplines, which is built on the basis of deepening the SRSTI (3 levels). Depending on the need to index individual branches, this rubricator can use up to ten levels. It is designed for systematization of information products and search in the VINITI RAS DB, which allows users to most fully and accurately formulate an information query. It is important to note that when articles are indexed each document can have an unlimited number of subject categories. 
Table 2. Distribution of analyzed journals by medical subject categories of the UPD DB

\begin{tabular}{|c|c|c|}
\hline$U P D$ headings & Number of journals & $\%$ \\
\hline Medical Sciences & 35 & 44.3 \\
\hline Medical sciences-Cardiovascular diseases & 6 & 7.60 \\
\hline Medical sciences-Oncology & 5 & 6.33 \\
\hline Medical sciences-Psychiatry and neurology & 4 & 5.06 \\
\hline Medical sciences-Orthopedics and traumatology & 4 & 5.06 \\
\hline Medical sciences-Pediatrics & 4 & 5.06 \\
\hline Medical sciences-Obstetrics and gynecology & 3 & 3.80 \\
\hline Medical sciences-Communicable diseases & 3 & 3.80 \\
\hline Medical sciences-Radiology and nuclear medicine & 2 & 2.53 \\
\hline Medical sciences-Urology and nephrology & 2 & 2.53 \\
\hline Medical sciences-Internal medicine & 2 & 2.53 \\
\hline Medical sciences-Respiratory diseases & 1 & 1.425 \\
\hline Medical sciences-Gastroenterology & 1 & 1.425 \\
\hline Medical sciences-Endocrinology & 1 & 1.425 \\
\hline Medical sciences-Hematology & 1 & 1.425 \\
\hline Medical sciences-Physical medicine and rehabilitation & 1 & 1.425 \\
\hline Medical sciences-Sports medicine & 1 & 1.425 \\
\hline Medical sciences-Forensic sciences & 1 & 1.425 \\
\hline Medical sciences-Experimental medicine & 1 & 1.425 \\
\hline Total number of the analyzed periodicals from the UPD DB & 79 & 100 \\
\hline
\end{tabular}

An example of in-depth indexing of scientific and technical information in the VINITI RAS DB for four medical journals of the analyzed array is given in Table 3 , which compares the SRSTI headings assigned to these journals in the eLIBRARY.RU DB with that assigned to the same journals in the VINITI RAS DB as a result of the indexing of articles from the processed issues of the corresponding journals (the categories are arranged in descending order of frequency). As can be seen from this table, journals that have only one general category in eLIBRARY.RU, for example, Medicine and Healthcare, were assigned four to nine other categories in the VINITI DB, which allows researchers to obtain more complete information about the scientific profile of the respective edition.

Another example of in-depth indexing in the VINITI RAS DB, but at the level of documents (articles), is shown in Table 4, which presents the subject categories assigned to three articles with the currently relevant subjects published in 2020 in one of the journals from the analyzed array: Infektsionnye bolezni: novosti, mneniya, obuchenie.

The first lines of the table show SRSTI codes followed by the VINITI RAS Rubricator codes (in italics). All three levels are indicated for the SRSTI codes, while the VINITI Rubricator codes are assigned up to the fifth level (at maximum nine levels can be assigned). In this example, we clearly see how the VINITI Rubricator deepens and supplements the
SRSTI headings. It should be noted that the structure and depth of the categories of the VINITI RAS Rubricator are updated annually based on the proposals of the Scientific and Technical Information Departments of the Institute on the relevant topics, since they must reflect the currently important issues of modern science and technology. Of all classifications considered in this article, this classification seems to be the most detailed; it allows the most accurate structuring of information and facilitates navigation through the information resource [21].

\section{NEW RUSSIAN MEDICAL JOURNALS INCLUDED IN THE SCOPUS AND WOS DATABASES}

Finally, let us consider the Russian medical journals founded over the past 10 years, which have entered the Scopus (22 titles) and WoS (5 titles) international databases. Table 5 presents the data for 15 journals extracted from the Scopus DB as well as their subject areas and quartiles $(\mathrm{Q})$, which characterize their rating in the corresponding subject category according to the SCImago analytical resource [2]. We should note that this table lacks other seven journals that have been included in Scopus quite recently; therefore they do not yet have relevant information:

(1) Arkhiv vnutrennei meditsiny ISSN 2226-6704.

(2) Head and Neck/Golova i sheya ISSN 2310-5194. 


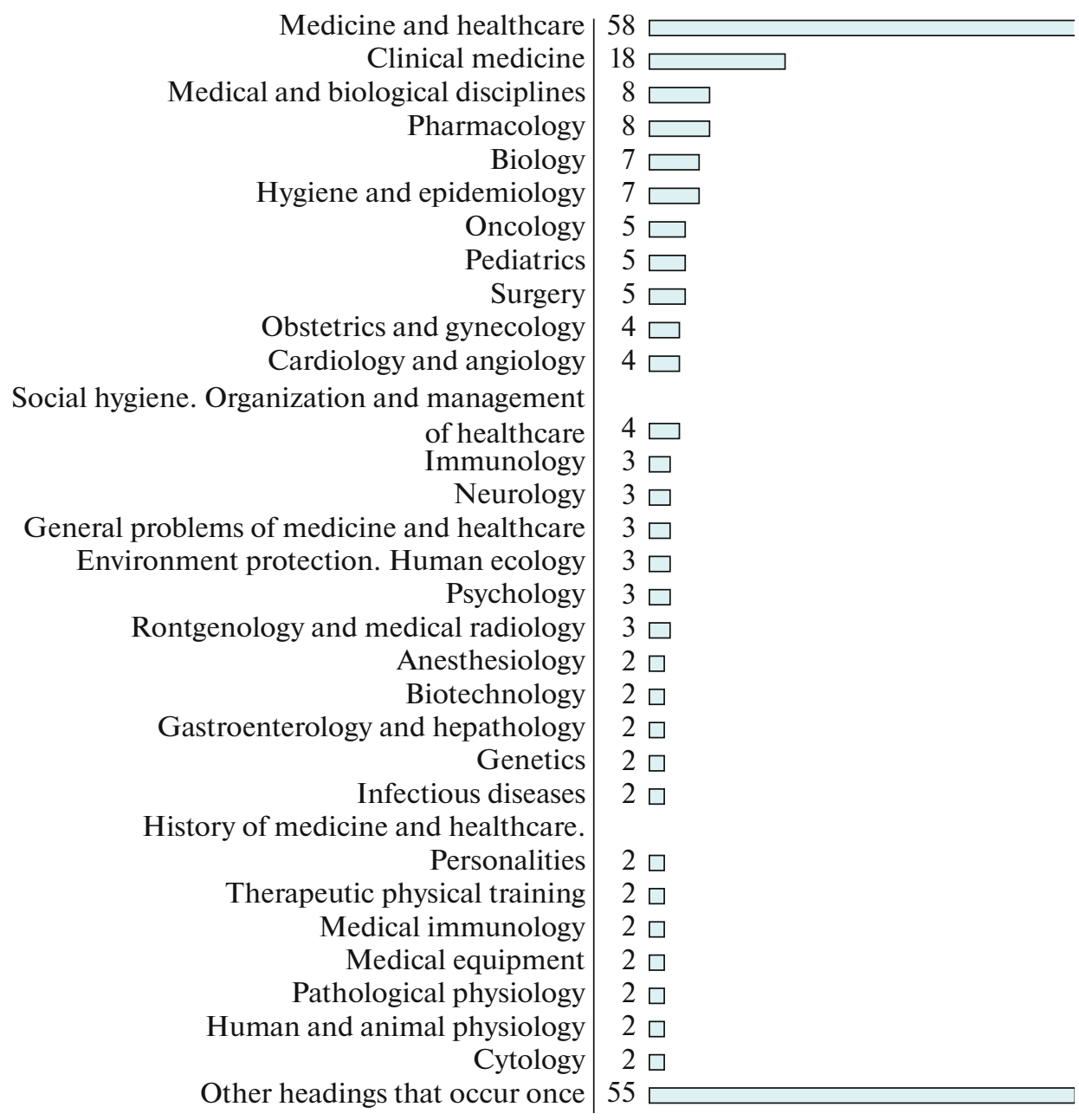

Fig. 4. The distribution of the analyzed medical journals (83) by the SRSTI subject categories according to the data of eLIBRARY.RU. The number of journals with the indicated categories is shown.

(3) Dokazatel'naya gastroenterologiya ISSN 23052260.

(4) Infektsionnye bolezni: novosti, mneniya, obuchenie ISSN 2305-3496.

(5) Kompleksnye problemy serdechno-sosudistykh zabolevanii ISSN 2306-1278.

(6) Klinicheskaya i eksperimental'naya morfologiya ISSN 2226-5988.

(7) Rossiiskii zhurnal detskoi gematologii i onkologii ISSN 2311-1267.

Analysis of the results shown in Table 5 indicates that the Russian journals included in the Scopus DB still have very modest scientometric characteristics: the indicator of their SJR (Scimago Journal Rank) rating ranges from 0.1 to 0.294 . For comparison, the American journal $C a-A$ Cancer Journal for Clinicians has the highest SJR in the subject area Medicine (62.937); among the Russian journals, the highest SJR is given to Biochemistry (Moscow), which is the translated version of the journal Biokhimiya (0.747). As for the quartiles that characterize the rating of journals in a certain subject category (depending on the citation rates, journals are divided into four groups $(\mathrm{Q} 1-\mathrm{Q} 4)$, most of our journals have the lowest quartile Q4. The exception is three journals with the Q3 quartile, and two of them have Q3 in medical categories: the journal Opera Medica et Physiologica published by the N.I. Lobachevsky National Research Nizhny Novgorod State University (Nizhny Novgorod) in the category Pathology and Forensic Medicine and in the category Physiology (medical), as well as the journal Ortopediya, travmotologiya i vosstanovitel'naya khirurgiya detskogo vozrasta published by the G.I. Turner Scientific Research Children's Orthopedic Institute (St. Petersburg) in the category (Pediatrics, Perinatology, and Child Health).

Considering the subject categories of Russian journals presented in the Scopus DB, we see that only 2 out of 15 have the general topic Medicine/General Medicine, in contrast to the results of the similar analysis in the UPD and eLIBRARY.RU DBs shown 
Table 3. Comparison of the subject categories of the analyzed journals according to the eLIBRARY.RU website with that in the VINITI RAS DB (SRSTI codes)

\begin{tabular}{|c|c|c|c|c|c|}
\hline Journal title & ISSN & $\begin{array}{c}\text { Year of } \\
\text { foundation }\end{array}$ & $\begin{array}{l}\text { RISC IF, } \\
2019\end{array}$ & $\begin{array}{c}\text { Subject } \\
\text { categories in } \\
\text { eLIBRARY.RU }\end{array}$ & Subject categories in VINITI RAS DB \\
\hline Medicus & $2409-563 X$ & 2014 & - & $\begin{array}{l}76.00 .00 . \text { Medi- } \\
\text { cine and } \\
\text { healthcare }\end{array}$ & $\begin{array}{l}\text { 34.39. Human and animal physiology } \\
\text { 34.25. Virology } \\
\text { 76.03. Biomedical disciplines } \\
\text { 34. 45. Pharmacology } \\
\text { 76.29. Clinical medicine } \\
\text { 76.31. Clinical pharmacology } \\
\text { 39.25. Clinical medicine } \\
\text { 34.43. Immunology } \\
\text { 34.27. Microbiology }\end{array}$ \\
\hline $\begin{array}{l}\text { Arkhiv vnutrennei } \\
\text { meditsiny }\end{array}$ & $2226-6704$ & 2011 & 0.595 & $\begin{array}{l}\text { 76.00.00. Medi- } \\
\text { cine and } \\
\text { healthcare }\end{array}$ & $\begin{array}{l}\text { 34.39. Human and animal physiology } \\
\text { 34.47. Toxicology } \\
\text { 76.31. Clinical pharmacology } \\
\text { 76.03. Biomedical disciplines } \\
\text { 34.43. Immunology } \\
\text { 34.25. Virology } \\
\text { 34.23. Genetics }\end{array}$ \\
\hline $\begin{array}{l}\text { Analiz riska } \\
\text { zdorovyu }\end{array}$ & $2308-1155$ & 2012 & 1.418 & $\begin{array}{l}\text { 05.11.61. Popu- } \\
\text { lation and } \\
\text { healthcare } \\
76.00 .00 . \text { Medi- } \\
\text { cine and } \\
\text { healthcare }\end{array}$ & $\begin{array}{l}\text { 34.47. Toxicology } \\
\text { 34.25. Virology } \\
\text { 34.39. Human and animal physiology } \\
\text { 62.99. Other problems of biotechnology } \\
\text { 76.33. Hygiene and epidemiology } \\
\text { 76.03. Biomedical disciplines } \\
\text { 39.25. Medical geography } \\
\text { 34.27. Microbiology }\end{array}$ \\
\hline $\begin{array}{l}\text { Onkologiya. } \\
\text { Journal named } \\
\text { after P.A. Gertsen }\end{array}$ & $2305-218 X$ & 2012 & 0.192 & $\begin{array}{l}76.29 .49 . \\
\text { Oncology }\end{array}$ & $\begin{array}{l}\text { 76.29. Clinical medicine } \\
\text { 76.03. Biomedical disciplines } \\
\text { 34.39. Human and animal physiology } \\
\text { 34.49. Radiation biology }\end{array}$ \\
\hline
\end{tabular}

* Two-year RISC impact factor in 2019, if available.

above, where such a category was assigned to the largest group of journals. The categories of other journals are specialized or highly specialized. This is an important observation that confirms the conclusions made by the authors of [8] that (narrowly) specialized periodicals which publish articles with good quality meeting the necessary design requirements, usually have a better chance of being included in the Scopus and $W o S$ databases, since the main requirements of experts involve the presence of a certain group of authors and readers that take interest in the journal.

In addition, it can be noted that some of the new Russian periodicals from our list that are included in the Scopus DB have just filled those niches of medical subject categories and medical-adjacent categories, which were identified according to [11] as potentially unfilled or poorly filled with journals of our country:
Geriatrics and Gerontology, Pathology and Forensic Medicine, Nursing, Health Policy, etc.

Table 6 shows five new Russian medical journals included in the Emerging Sources Citation Index $(E S C I)$ : a list of citation of new sources, which is a part of the main collection of the Web of Science Core Collection DB with the possibility of transition after a certain period of time to the Journal Citation Reports index, where the periodicals are assigned bibliometric indicators based on citation data. Four out of five journals are simultaneously included in the Scopus DB, but one (Cardiometry) is not. This table also shows the subject categories assigned to these journals in various databases; in some cases there are discrepancies in the categories or insufficiently precise specialization of the subjects. 
Table 4. An example of indexing articles in the VINITI RAS DB from the journal Infektsionnye bolezni: novosti, mneniya, obuchenie

\begin{tabular}{|c|c|}
\hline Bibliographic data of the document & $\begin{array}{c}\text { Subject categories of the document according to the SRSTI } \\
\text { and the VINITI RAS Rubricator (italics) }\end{array}$ \\
\hline $\begin{array}{l}\text { Granovskaya, M.V., Zaslavskaya, K.Ya. } \\
\text { COVID-19-is it a set of symptoms or a systemic pathology? } \\
\text { Clinical lecture. Part } 1 . \text { Features of multiple organ disor- } \\
\text { ders// Infektsionnye bolezni: novosti, mneniya, obuchenie, } \\
\text { 2020, vol. 9, No. 3, app., pp. 3-9. Rus. }\end{array}$ & $\begin{array}{l}\text { 34.25.23. Antiviral immunity } \\
\text { 34.25.29. Ecological issues and epidemiology of viruses } \\
\text { 761.03.41.07. Clinical manifestations in viral infections * } \\
\text { 341.25.23.33. Immunopathology in viral infections } \\
\text { 341.25.29.17.41. Coronaviridae }\end{array}$ \\
\hline $\begin{array}{l}\text { Demidova, T.Yu., Volkova, E.I., Gritskevich, E.Yu. Obesity } \\
\text { and COVID-19: a fatal relationship // Infektsionnye bolezni: } \\
\text { novosti, mneniya, obuchenie, 2020, vol. 9, No. 3, app., pp. } \\
\text { 25-32. Rus. }\end{array}$ & $\begin{array}{l}\text { 76.03.41. Medical Virology } \\
\text { 34.25.29. Environmental issues and epidemiology of viruses } \\
\text { 761.03.41.07. Clinical manifestations in viral infections } \\
\text { 341.25.29.17.41. Coronaviridae } \\
\text { 761.03.41.09. Treatment of viral diseases }\end{array}$ \\
\hline $\begin{array}{l}\text { Yokota, Sh., Kuroyva, E., Nishioka, K. New coronavirus dis- } \\
\text { ease (COVID-19) and cytokine storm. Prospects for effective } \\
\text { treatment from the point of view of the pathophysiology of the } \\
\text { inflammatory process// Infektsionnye bolezni: novosti, } \\
\text { mneniya, obuchenie, 2020, vol. } 9 \text {, No. 4, pp. } 13-25 . \text { Rus. }\end{array}$ & $\begin{array}{l}\text { 34.25.23. Antiviral immunity } \\
\text { 34.25.29. Ecological issues and epidemiology of viruses } \\
\text { 76.03.41. Medical virology } \\
\text { 341.25.23.25. Interferon and other cytokines } \\
\text { 341.25.29.17.41. Coronaviridae } \\
\text { 761.03.41.07. Clinical manifestations in viral infections } \\
\text { 761.03.41.09. Treatment of viral diseases }\end{array}$ \\
\hline
\end{tabular}

* Codes of the VINITI RAS Rubricator are given in italics.

\section{CONCLUSIONS}

The analysis of new scientific medical journals that have appeared in Russia over the past 10 years (with the year of foundation in 2010-2019) has made it possible to identify 84 periodicals which can be found in three large international databases: Ulrich's Periodicals Directory (UPD), Scopus and Web of Science. The selection of journals with an emphasis on practical medicine was carried out using a methodology developed at the VINITI RAS with the involvement of data obtained from the Russian resource eLIBRARY.RU.

With a variety of solutions for the development model of journals, the following facts and patterns can be underlined. Analysis of the dynamics of the emergence of new journals of this type shows a tendency towards a gradual decrease in their number, which may presumably be due to the policy of scientific administration, which requires that scientists publish their articles in well-known journals included in international citation databases.

An increasing number of scientific journals are switching to the electronic form of presentation of materials (one-quarter of them exist exclusively in online format), while information in most periodicals is in open access. Our research revealed a good result regarding the inclusion of Russian journals into international citation databases: 22 journals (26\%) were included in the Scopus DB, 5 were included in the $\mathrm{Web}$ of Science (ESCI) DB, although at the moment they have modest results there (quartile Q4 and only in two cases Q3) or have no indicators yet. The overwhelming majority of journals are fairly well represented in Russian resources: eLIBRARY.RU (83, of which 70 are included in the RISC), the VINITI RAS DB (56), in the Higher Attestation Commission list (54), and are also available in the State Central Scientific Medical Library DB (58). Journals are published more often by professional publishing houses or universities and less often by scientific societies, associations, centers, research institutes, etc. An increase in the activity of Russian regions in the publication of new scientific medical journals has been noted.

We have obtained a more meaningful result of analyzing the subject categories of the journals by combining information from various databases, although there are significant differences in attribution to the category. Most of the journals in the UPD and eLIBRARY.RU DBs have general medical categories, while the journals in the Scopus and $W o S$ DBs have more specific categories. There is a scattering of subjects in various fields of medicine, as well as the filling of some thematic niches in the Scopus DB is observed, which are poorly filled with Russian journals. Various examples show that the most useful system among all the considered classifications of subject categories is the system for in-depth indexing of subjects using the SRSTI headings and the VINITI RAS Rubricator, which makes it possible to structure information and facilitate navigation through the information resource most accurately.

In general, the data obtained indicate a fairly active development of new scientific medical periodicals in Russia, which gives hope for continued progress in this 


\begin{tabular}{|c|c|c|c|c|c|c|c|c|c|c|c|c|c|c|c|}
\hline 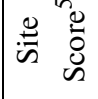 & $\hat{o}$ & & $\stackrel{+}{0}$ & $\ddot{0}$ & $\stackrel{+}{0}$ & $\overrightarrow{0}=$ & $\stackrel{t}{0}$ & : & $\stackrel{0}{0}: \stackrel{t}{0}$ & $\tilde{o}$ & $\overline{0}$ & $\tilde{c}:$ & & : & 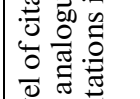 \\
\hline 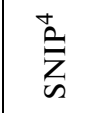 & $\stackrel{2}{a}$ & & 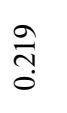 & $\stackrel{\substack{n \\
0}}{0}$ & 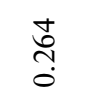 & $\begin{array}{l}\hat{\hat{S}} \\
0 \\
0 \\
0\end{array}$ & 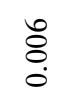 & 1 & 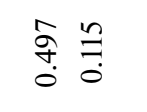 & $\stackrel{+}{+}$ & $\stackrel{\overbrace{}}{\Im}$ & \begin{tabular}{ll}
0 & \multirow{1}{*}{} \\
0 & 0 \\
0 & 0
\end{tabular} & & & 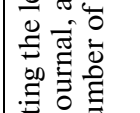 \\
\hline$\stackrel{m}{\frac{a}{n}}$ & 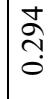 & & $\frac{7}{3}$ & $\hat{\Xi}$ & $\stackrel{\infty}{0}$ & $\frac{8}{0} \frac{\sqrt{n}}{0}$ & $\frac{8}{0}$ & $\stackrel{0}{\stackrel{0}{0}}$ & $\stackrel{\substack{m \\
0}}{0}$ & సे & $\stackrel{\infty}{7}$ & $\underset{7}{\stackrel{7}{7}} \stackrel{9}{7}$ & & ?. & 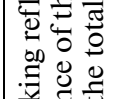 \\
\hline 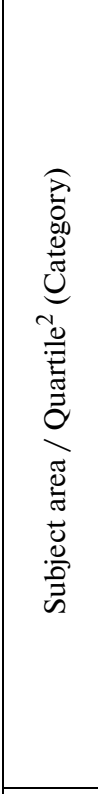 & 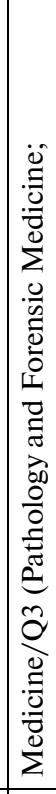 & 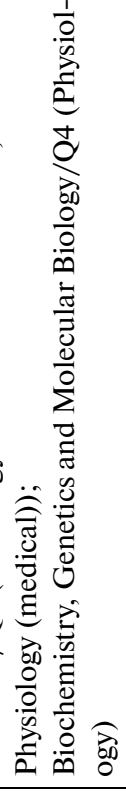 & 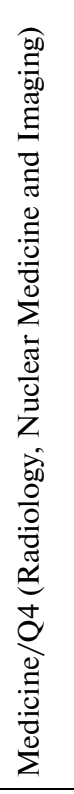 & 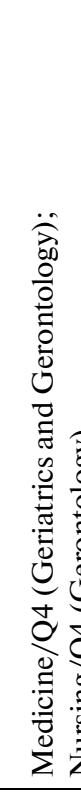 & 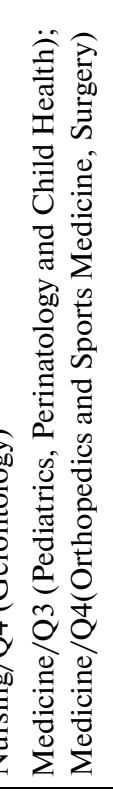 & 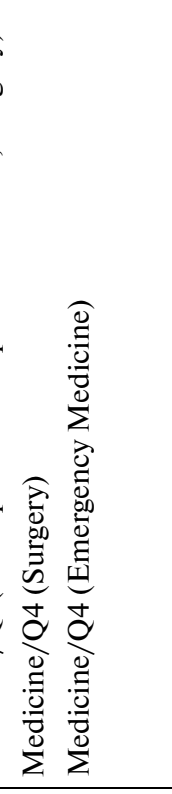 & 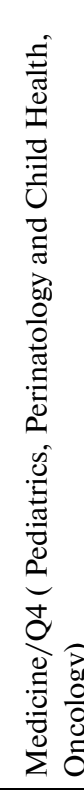 & 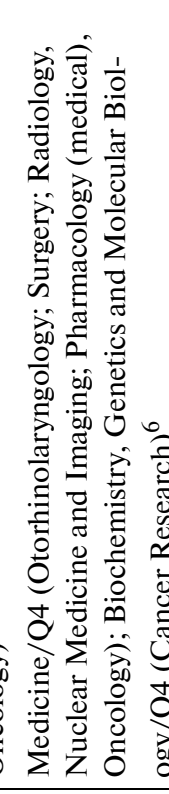 & 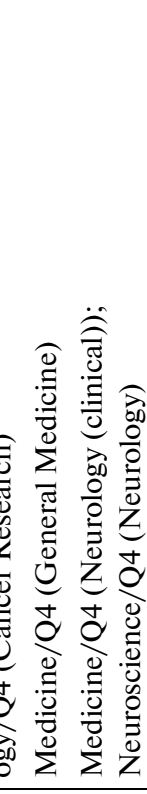 & 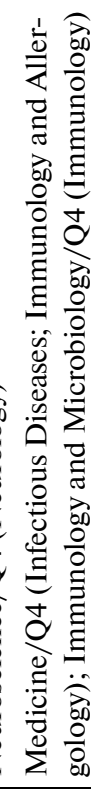 & 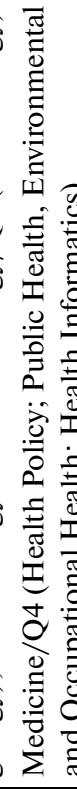 & 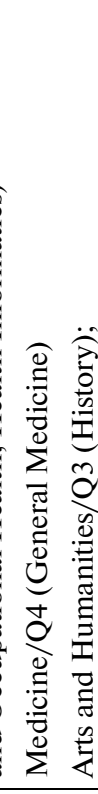 & 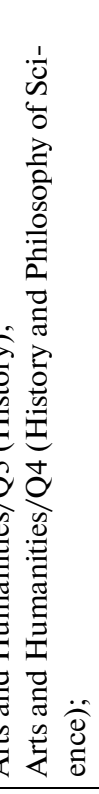 & 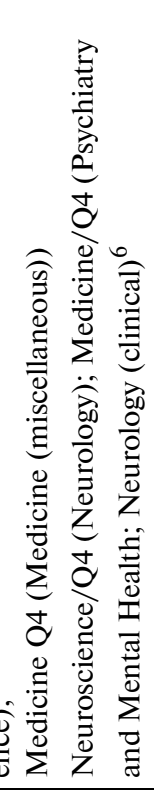 & 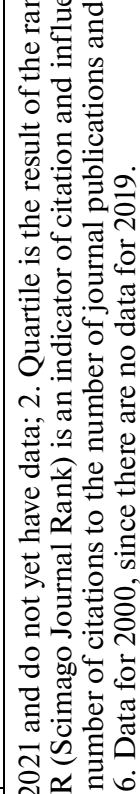 \\
\hline 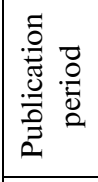 & $\begin{array}{l}\overrightarrow{\widetilde{d}} \\
i \\
n \\
\check{\overbrace{}}\end{array}$ & & 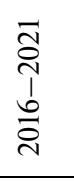 & $\begin{array}{l}\overrightarrow{\widetilde{d}} \\
\stackrel{N}{1} \\
\bar{\Xi}\end{array}$ & 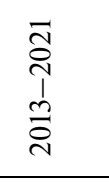 & 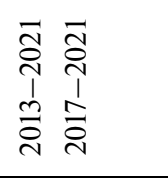 & $\begin{array}{l}a \\
\vec{i} \\
i \\
\infty \\
\dot{\sim}\end{array}$ & $\begin{array}{l}\stackrel{\overbrace{}}{~} \\
\stackrel{\sim}{1} \\
\infty \\
\stackrel{\sim}{\pi}\end{array}$ & 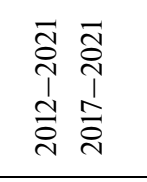 & 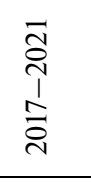 & 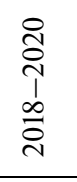 & 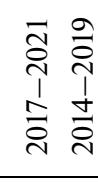 & & 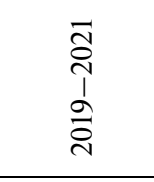 & $\begin{array}{l}\stackrel{2}{0} \\
\stackrel{2}{1} \\
\cong \\
\Xi\end{array}$ \\
\hline 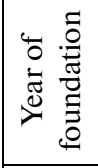 & $\frac{n}{2}$ & & $\overline{\bar{乛}}$ & $\overline{\bar{\lambda}}$ & $\stackrel{m}{\bar{i}}$ & $\stackrel{m}{\vec{i}} \bar{\Xi}$ & $\stackrel{+}{\vec{i}}$ & $\stackrel{ }{\stackrel{1}{1}}$ & 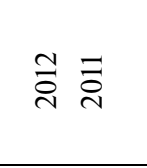 & $\overline{\vec{\sim}}$ & ָี & 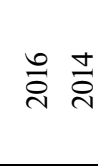 & & हे & $\begin{array}{l}0.0 \\
0 \\
0 \\
0 \\
0 \\
0\end{array}$ \\
\hline $\begin{array}{l}Z \\
\approx \\
\approx\end{array}$ & 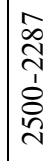 & & 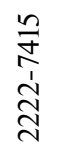 & 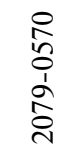 & 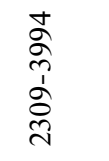 & 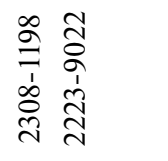 & $\begin{array}{l}\hat{\sigma} \\
\hat{a} \\
\hat{\vec{\sigma}}\end{array}$ & 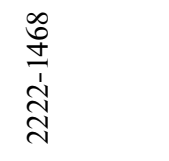 & 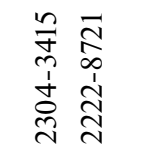 & 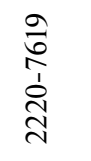 & 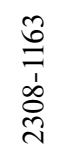 & 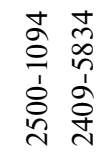 & & 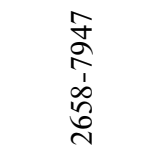 & $\begin{array}{l}0 \\
0 \\
0 \\
:\end{array}$ \\
\hline 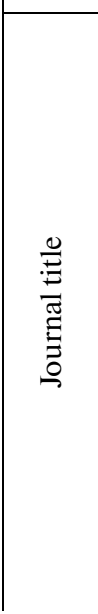 & 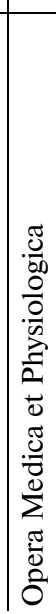 & & 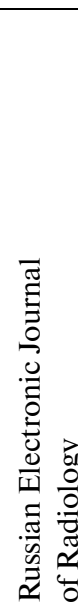 & 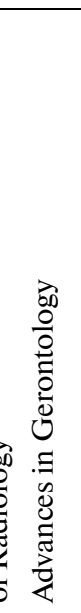 & 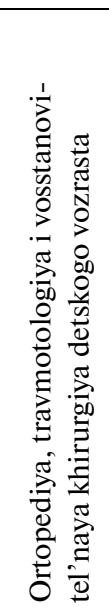 & 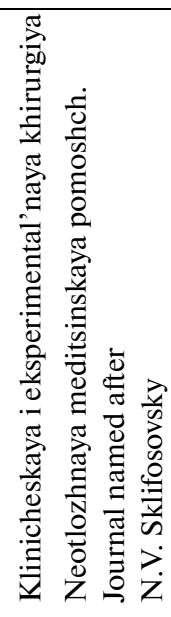 & 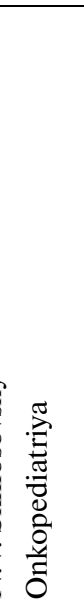 & 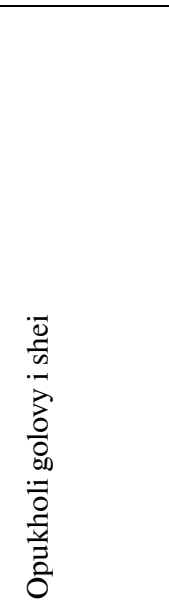 & 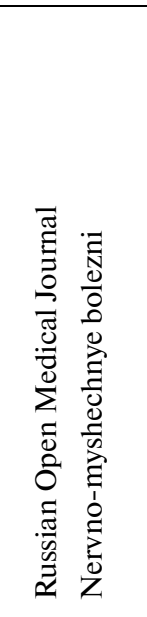 & 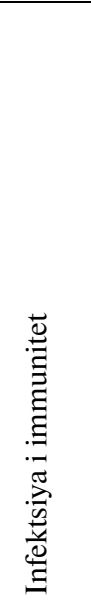 & 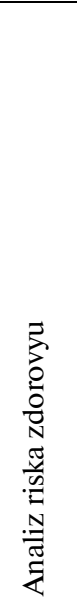 & 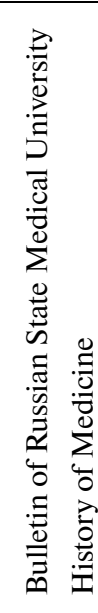 & & 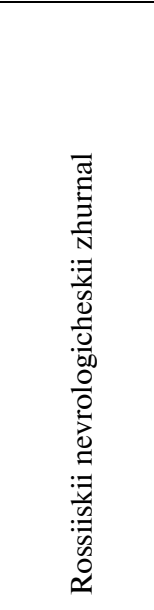 & 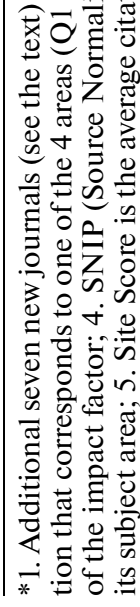 \\
\hline
\end{tabular}


Table 6. Subject categories of Russian medical journals with the year of foundation in 2010-2019 included in the ESCI of the WoS DB

\begin{tabular}{|c|c|c|c|}
\hline Journal title & ISSN & $\begin{array}{c}\text { Year } \\
\text { of foundation }\end{array}$ & Subject categories in various databases \\
\hline Advances in Gerontology & $2079-0570$ & 2011 & $\begin{array}{l}\text { WoS: Geriatrics Gerontology } \\
\text { Scopus: Medicine/Geriatrics and Gerontology; } \\
\text { Nursing/Gerontology } \\
\text { eLIBRARY.RU: Medicine and healthcare } \\
\text { UPD: Gerontology and Geriatrics }\end{array}$ \\
\hline Cardiometry & $2304-7232$ & 2012 & $\begin{array}{l}\text { WoS: Medical Laboratory Technology } \\
\text { eLIBRARY.RU: Medicine and healthcare } \\
\text { UPD: Medical Sciences-Cardiovascular Diseases }\end{array}$ \\
\hline Russian Open Medical Journal & $2304-3415$ & 2012 & $\begin{array}{l}\text { WoS: Medicine General Internal } \\
\text { Scopus: Medicine/General Medicine } \\
\text { eLIBRARY.RU: Medicine and healthcare; Biology } \\
\text { UPD: Medical Sciences }\end{array}$ \\
\hline Infektsiya i immunitet & $2220-7619$ & 2011 & $\begin{array}{l}\text { WoS: Infectious Diseases } \\
\text { Scopus: Medicine/Infectious Diseases; Immunology and } \\
\text { Allergology; Immunology and Microbiology/Immunology } \\
\text { eLIBRARY.RU: Biology; Virology; Microbiology; Immu- } \\
\text { nology; Medicine and healthcare; Medical Virology, Medi- } \\
\text { cal Microbiology, Medical Immunology } \\
\text { UPD: Medical Sciences-Communicable Diseases }\end{array}$ \\
\hline $\begin{array}{l}\text { Bulletin of Russian State Medi- } \\
\text { cal University }\end{array}$ & $2500-1094$ & 2016 & $\begin{array}{l}\text { WoS: Medicine General Internal } \\
\text { Scopus: Medicine/General Medicine } \\
\text { eLIBRARY.RU: Medicine and healthcare; Biology }\end{array}$ \\
\hline
\end{tabular}

area, requires their support at all levels, since this will certainly contribute to the successful development of national medicine and healthcare.

\section{FUNDING}

The work was carried out in accordance with the plan of research work of the State Assignment of the VINITI RAS, topic 0003-2019-0003 Analytical studies of the flow of scientific and technical information, the development of an integrated information resource acquisition system and the formation of thematic, classification and subject profiles in priority areas of science and engineering and technology, R\&D registration number AAAA-A19-119022290079-6.

\section{REFERENCES}

1. Ulrichsweb: Global Serials Directory. https://ulrichsweb.serialssolutions.com/. Cited February 23, 2021.

2. SJR: SCImago Journal \& Country Rank. http://www.scimagojr.com. Cited February 23, 2021.

3. Scopus. http://www.scopus.com/search/form.uri?display=basic. Cited February 23, 2021.

4. Web of Science. Journal Citation Reports. https://clarivate.com/webofsciencegroup/solutions/journal-citation-reports/. Cited February 23, 2021.
5. Kirillova, O.V., State and prospects of representation of Russian medical journals and publications in Scopus database, Vestn. Eksp. Klin. Khirurg., 2014, vol. 7, no. 1, pp. $10-24$.

6. Scientific Electronic Library eLIBRARY.RU. https://elibrary.ru/querybox.asp?scope $=$ newquery. Cited February 23, 2021.

7. Nikoda, V.V. and Kirillova, O.V., Medical journals in Russian Federation: Review and analysis, in Nauchnoe izdanie mezhdunarodnogo urovnya - 2016: Reshenie problem izdatel'skoi etiki, retsenzirovaniya i podgotovki publikatsii (Scientific Publication of International Level 2016: Solution of Problems of Publishing Ethics, Reviewing, and Preparation of Publications), Yekaterinburg: Ural. Univ., 2016.

8. Nikoda, V.V., Kirillova, O.V., Serebrennikova, S.L., and Khil'kevich, E.G., Analysis and assessment of the thematic distribution of Russian medical journals in Scopus, Nauch. Redaktor Izdatel', 2017, vol. 2, no. 2-4, pp. 71-83. https://doi.org/10.24069/2542-0267-2017-2-4-71-83

9. Kharybina, T.N. and Beskaravainaya, E.V., Russian medical journals in foreign thematic databases, Medline.ru. Ross. Biomed. Zh., 2010, vol. 11, no. 1, pp. 322330.

10. Starodubov, V.I., Kuznetsov, S.L., Kurakova, N.G., Tsvetkova, L.A., Arefiev, P.G., Ivanov, A.V., and Eremchenko, O.A., Publication activity of the Russian medicine in focus of national science policy: Estimating 
the feasibility of policy targets, Vestn. Ross. Akad. Med. Nauk, 2013, vol. 68, no. 3, pp. 8-14.

https://doi.org/10.15690/vramn.v68i3.595

11. Ponomarenko, G.N., Sokurov, A.V., Smirnova, L.M., Serebryak, T.V., Ermolenko, T.V., and Ivanova, N.V., Medical rehabilitation: Domestic scientific publication stream in the Web of Science database, Fiz. Reabilitatsionnaya Med., 2020, vol. 2, no. 1, pp. 5-24. https://doi.org/10.26211/2658-4522-2020-2-1-5-14

12. Vlassov, V.V. and Danishevskiy, K.D., Biomedical journals and databases in Russia and Russian language in the former Soviet Union and beyond, Emerging Themes Epidemiol., 2008, vol. 5, p. 15. https://doi.org/10.1186/1742-7622-5-15

13. Soboleva, N.O. and Evdokimenkova, Yu.B., Publication activity in the field of medicinal chemistry in 20082017: russian research in the global flow, Russ. Chem. Bull., 2018, vol. 67, pp. 1936-1941. https://doi.org/10.1007/s11172-018-2312-3

14. Ryu, D.A., The development of high impact national and regional journals in medicine and the health sciences, Nauch. Redaktor Izdatel', 2020, vol. 5, no. 2, pp. $113-122$.

https://doi.org/10.24069/2542-0267-2020-2-113-122

15. Web of Science Core Collection. https://clarivate.com/webofsciencegroup/solutions/web-of-science-core-collection/. Cited February 23, 2021.
16. Central Scientific Medical Library. http://www.em11.ru/. Cited February 23, 2021.

17. Database of the All-Russian Institute of Scientific and Technical Information. http://www.viniti.ru/products/viniti-database. Cited February 23, 2021.

18. Mazov, N.A., Gureev, V.N., and Kalenov, N.E., Some assessments of the list of journals in the Russian Science Citation Index, Herald Russ. Acad. Sci., 2018, vol. 88 , no. 2 , pp. $133-141$. https://doi.org/10.1134/S1019331618020053

19. State Classification System of Scientific and Technical Information. http://www.viniti.ru/products/classification-systems/rubricator-grnti. Cited February 23, 2021.

20. Classification System of Knowledge Branches of the All-Russian Institute of Scientific and Technical Information, Russian Academy of Sciences. http://www.viniti.ru/products/classification-systems/ rubricator-viniti. Cited February 23, 2021.

21. Solov'eva, I.M. and Dmitrieva, E.Yu., Experience of work with classification systems in the All-Russian Institute of Scientific and Technical Information, Russian Academy of Sciences, Nauchn.-Tekhn. Inform., Ser. 1. Organ. Metod. Inf. Rab., 2015, no. 3, pp. 23-26.

Translated by L. Solovyova 